da Silva, W. B., Cajaiba, R. L., \& Périco, P. (2021). Ant diversity sampling in the Brazilian Amazon: a comparison of litter collection and pitfall trapping. Revista de Biología Tropical, 69(3), 865-872. https://doi.org/10.15517/rbt. v69i3.46872

Biologín Tropical

https://doi.org/10.15517/rbt.v69i3.46872

\title{
Ant diversity sampling in the Brazilian Amazon: a comparison of litter collection and pitfall trapping
}

Wully B. da Silva1,2*; (D) https://orcid.org/0000-0002-6209-4984

Reinaldo L. Cajaiba ${ }^{3}$; (D) https://orcid.org/0000-0003-0176-9201

Eduardo Périco ${ }^{1}$; (D) https://orcid.org/0000-0002-2926-6246

1. Laboratory of Ecology and Evolution, University of Taquari Valley, Lajeado, Rio Grande do Sul, Brazil; wully_bio@ hotmail.com (Correspondence*), perico@univates.br

2. Federal Institute of Education, Science and Technology of Pará, Itaituba, Para, Brazil.

3. Laboratory of Ecology and Conservation, Federal Institute of Education, Science and Technology of Maranhão, Buriticupu, Maranhão, Brazil; reinaldocajaiba@hotmail.com

Received 05-V-2021. C Corrected 08-VII-2021. Accepted 19-VIII-2021.

\begin{abstract}
Introduction: Ants in tropical forests are a hyper-diverse group that plays important ecological roles. Several studies on tropical forests have used different sampling protocols to capture soil ants, making it difficult to compare responses and patterns of diversity between studies. Thus, research that compares different well-structured and standardized sampling methodologies to adequately estimate the richness of ant species in tropical forests is necessary.

Objective: In this study, we examined the combination of catches with pitfall traps with and without baits and litter collections for soil ant sampling.

Methods: In the fall traps, we use two baited (sardines and bananas) and one non-baited. For the manual collections (litter sampling), the litter and only the topsoil of the loose soil were collected.

Results: We found that traps containing sardine baits collected a greater abundance of ants, whereas non-baited traps collected a greater richness of ant species. On the other hand, litter collections captured the largest number of exclusive species, presenting a different species composition from the pitfall traps (with and without baits). In general, baited traps showed greater abundance in more degraded locations, while manual collections and unbaited pitfalls captured more individuals in preserved environments.

Conclusions: Our results provide evidence that, for accurate sampling of soil ant assemblages in tropical forests, the use of different methodologies is necessary to capture a greater diversity of species because the methods differ in effectiveness according to habitat.
\end{abstract}

Key words: ant community; Formicidae; inventory; sampling methods; tropical forests.

Studies of soil macrofauna require wellstructured and standardized sampling methodologies to adequately estimate species richness and uniformity (Véle et al., 2009). However, it is challenging to estimate species richness in megadiverse regions because the techniques used by researchers do not always provide a representative sample of total richness (Agosti \& Alonso, 2001; Orsolon-Souza et al., 2011; Tista \& Fiedler, 2011). Ants are a hyperdiverse group in tropical forests and particularly important in the soil macrofauna, as they are 
highly abundant, have a wide geographical distribution, and occupy a wide variety of niches (Andersen \& Majer, 2004; Solar et al., 2016; Tiede et al., 2017). They play critical ecological roles, acting as herbivores, seed dispersers, or predators of other arthropods and scavengers (Del Toro et al., 2012; Andersen, 2019). In addition, they contribute in an extraordinary way to the edaphic processes, such as the movement of water and soil and the cycling of nutrients (Sousa-Souto et al., 2007). Because of these characteristics, ants have frequently been used as a focal taxon in biodiversity studies or as bioindicators in soil management studies (Schimidt \& Solar, 2010; Pacheco \& Vasconcelos, 2012).

Several methodologies have been used to collect ants from the soil, each of which has limitations. No method can collect all the species that inhabit a specific area because these species usually have a great diversity of foraging and nesting habits (Pacheco \& Vasconcelos, 2012; Salata et al., 2020). Ant community researchers suggest combining different techniques as the best way to estimate ant richness and abundance (Delabie et al., 2000a; Longino et al., 2002; Gotelli et al., 2011). Therefore, it is important to compare the efficiency of the various techniques for sampling ant diversity in one place to advance knowledge about ant fauna in hyper-diverse regions, especially in the litter (Castilho et al., 2007; Veiga-Ferreira et al., 2010; Hanisch et al., 2018). As a result, many ant inventories employ more than one sampling technique because their use in combination often increases sampling efficiency (Wong \& Guénard, 2017; Lee \& Guénard, 2019; Salata et al., 2020).

Ants have been the subject of several ecological studies and have been sampled by various methods, including pitfall traps, bait traps, litter sampling, fogging, beating the vegetation and manual harvesting (Orsolon-Souza et al., 2011; Yusah et al., 2012; Cajaiba \& Silva, 2014; Antoniazzi et al., 2020). In this study, we compared the performance of two methods usually used for catching soil ants: manual litter collection and pitfall traps (Nakamura et al.,
2007). Although the combined use of these two techniques results in some redundancy (Lopes \& Vasconcelos, 2008; Souza et al., 2012), they are essential for estimating species richness in megadiverse regions (Delabie et al., 2000b). In pitfall traps, we used two types of baits, banana and sardines, in addition to the non-baited, that is, pitfall without baits. Our objective was to test whether there are effects of different sampling techniques on the abundance, richness, and composition of soil ant species between each method. In addressing these questions, we attempt to build a framework of reference, which should help researchers to evaluate the trade-offs between sampling completeness and the costs and time required (Souza et al., 2012).

\section{MATERIALS AND METHODS}

Study location: The study was carried out in the state of Pará, Northern Brazil, in an Amazon rainforest region, during the year 2015 , in the months of February/March (rainy season), June (final of rainy season and early dry season) and September/October (dry season). We conducted collections in areas with five different land uses and land cover, which were classified into: i) preserved forest - PF (area with little or no disturbance identified in the last hundred years, where we used geoprocessing of satellite images, interviews with residents, and on-site visits); ii) secondary forest - SF15, in an intermediate stage of regeneration with 15 years of fallow; iii) secondary forest - SF5, in an initial stage of regeneration with five years of fallow; as in preserved forests, we used geoprocessing of satellite images, interviews with residents, and on-site visits to estimate the age of secondary forests; iv) agricultural areas $-\mathrm{Ag}$ (cocoa crop, Theobroma cacao), and v) pasture area - Pa (extensive livestock) - see details of the study areas in Cajaiba et al. (2020). In each of these habitats, two areas were sampled, totaling 10 sampled areas.

Ant sampling: Pitfall traps were used to collect the ants. The traps were $75 \mathrm{~mm}$ in diameter and $110 \mathrm{~mm}$ deep, containing 
approximately $500 \mathrm{ml}$ of solution (water, coarse salt for preserving dead animals, and neutral detergent to break the surface tension of the water), and covered by a suspended roof to prevent rainwater from entering. The traps were installed at seven random points in each study site, with a minimum distance of $150 \mathrm{~m}$ from each other, always considering a minimum distance of $150 \mathrm{~m}$ from the edge to prevent the sample from being influenced by the edge effect (Lacasella et al., 2015). Three traps were installed at each point, two baited (sardines and bananas) and one non-baited, $10 \mathrm{~m}$ apart, totaling 21 pitfall traps at each location. Each trap remained installed for $48 \mathrm{~h}$, with the protocol being repeated in all areas and periods of collection, totaling a sampling effort of 630 traps (see Digital Appendix 1, for details of the sample design).

For the manual collections (litter sampling), 10 random sampling points of $1 \mathrm{~m}^{2}$ (1x1 m - total of 300 sampled points, Digital Appendix 2) with a distance of $100 \mathrm{~m}$ between them were selected for each ecosystem and sampling period. At each collection point, the litter and only the topsoil of the loose soil were scraped gently with a metal spatula to include those ants in the samples that fell from the litter during the collection procedure. The litter here is defined as the layer of leaves and debris that can be easily removed from the more compact soil (Ivanov \& Keiper, 2009; Da Silva et al., 2018). We refrained from simply separating the litter and the soil, considering that if the litter is removed, ants can escape and hide in the topsoil (Nakamura et al., 2007; Cajaiba et al., 2017). Each soil and litter sample was placed in a tightly closed tissue bag and kept in an insulated box. All materials were screened in the laboratory, with detailed searches on the leaves, branches, and soil. The ants were extracted manually and preserved in $70 \%$ ethanol solution. Ants (captured in all collection methods) were identified according to keys (Bolton, 1994; Palácio \& Fernández, 2003; Baccaro et al., 2015), and reference material in the Laboratory of Ecology and Conservation, Federal
Institute of Education, Science and Technology of Maranhão.

Data analysis: To analyze the effects of habitat types on the species richness and abundance of ants, we performed generalized linear model (GLM). Models were analyzed with a Poisson distribution (to analyze species richness) and a negative binomial distribution (to analyze abundance), given the high overdispersion found in ants abundance. We performed pairwise contrast analyses to detect differences among treatments (Crawley, 2013). Statistical analyses were conducted using the lme4 package in $\mathrm{R}$ software version 3.2.0 ( $\mathrm{R}$ Core Team, 2016; Bates et al., 2019). The taxonomic composition of ant communities between capture methods was compared using a multivariate analysis of permutational variance (PERMANOVA). Non-metric multidimensional scale (NMDS) graphs were used to assist in the interpretation of the results found with PERMANOVAs (see Anderson (2001) for a similar procedure).

\section{RESULTS}

Using the various collection techniques in the different sampled environments, we collected 9727 individuals and 131 ant species, distributed in 31 genera and 8 subfamilies. The richest subfamilies were Myrmicinae (66 species, 5029 individuals) and Ponerinae (25 species, 2786 individuals), while the most representative genera were Pheidole (15 species and 2872 individuals), Camponotus (12 species and 1016 individuals) and Solenopsis (10 species and 1128 individuals).

Traps containing sardine baits showed a greater abundance of ants (3 207 individuals), followed by banana baits (2 529 individuals). Non-baited traps collected greater species richness (89 species), followed by manual collection (83 species). The GLM tests showed statistically significant differences of species abundance according to different collection methods $(F=14.77, \mathrm{P}<0.001)$. Significant differences were found between all the 

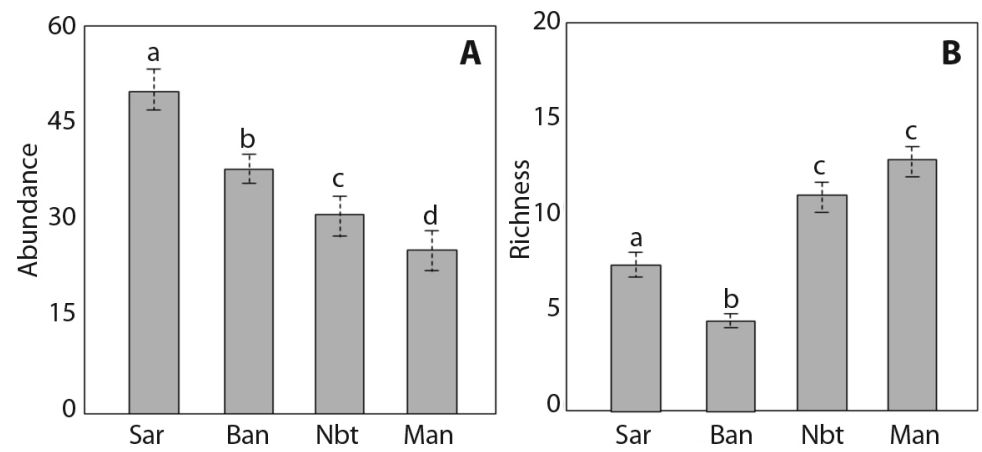

Fig. 1. Box plot expressing the differences in the median values for A. Abundance and B. Richness of the ant community using the different collection methods. The values followed by the same letters are not significantly different. Sar $=$ sardine, Ban $=$ banana, $\mathrm{Nbt}=$ non-baited, Man $=$ manual.

collection methods (Fig. 1A). The GLM tests also showed statistically significant differences of species richness according to the different methods $(\mathrm{F}=11.98, \mathrm{P}<0.001)$. According to a paired test, there were no significant differences between the non-baited and manual means $(\mathrm{P}>0.05)$ (Fig. 1B).

In terms of exclusivity, leaf-litter manual sampling gathered the largest number of exclusive species (21 species). We discovered that the pitfall, regardless of the baits used, captured larger ants, while manual collections captured smaller ants with less foraging capacity. The species composition differed between the different collection methods (Permanova $\mathrm{F}=259.2$, $\mathrm{P}<0.001$ ) (Table 1).

These data were corroborated with the NMDS, where the species collected using different methods (pitfall and manual) and different baits differed from each other. Bait traps have a greater overlap of species (54 shared species), while non-baited pitfalls and manual collections were separated from the other methods (Fig. 2).

When ant richness was tested for the different collection methods within each habitat, significant differences were found (Digital Appendix 3). In general, baited traps were more abundant in more degraded places (pasture and secondary forest with five years of regeneration and cocoa, respectively), while manual collections and non-baited pitfall captured more
TABLE 1

PERMANOVA results comparing the composition of ant assemblages between different sampling methods

\begin{tabular}{lcccc}
\hline & Sardine & Banana & Non-baited & Manual \\
\hline Sardine & - & 0.001 & 0.001 & 0.001 \\
Banana & 27.9 & - & 0.01 & 0.001 \\
Non-baited & 18.8 & 18.5 & - & 0.01 \\
Manual & 6.80 & 15.4 & 28.2 & - \\
\hline
\end{tabular}

PERMANOVA based on the similarity of Bray-Curtis using 9999 permutations, $\mathrm{F}=259.2, \mathrm{P}<0.001$.

individuals in more preserved environments. These differences were confirmed using the GLM test (Digital Appendix 4). Species richness followed the same pattern, in which the different methods were significant within the sampled environments. Manual collection and non-baited pitfall showed greater species richness in primary forests, while sardine and banana baits collected more species in pasture and cocoa areas. On the other hand, baited traps with banana and sardines showed lower species richness in primary forest areas (Digital Appendix 4). The taxonomic composition of ants captured by habitat showed significant differences between the different collection methods, as demonstrated by PERMANOVA and NMDS (see Digital Appendix 3 and Digital Appendix 5 for the associated differences between baits in each studied habitat). 


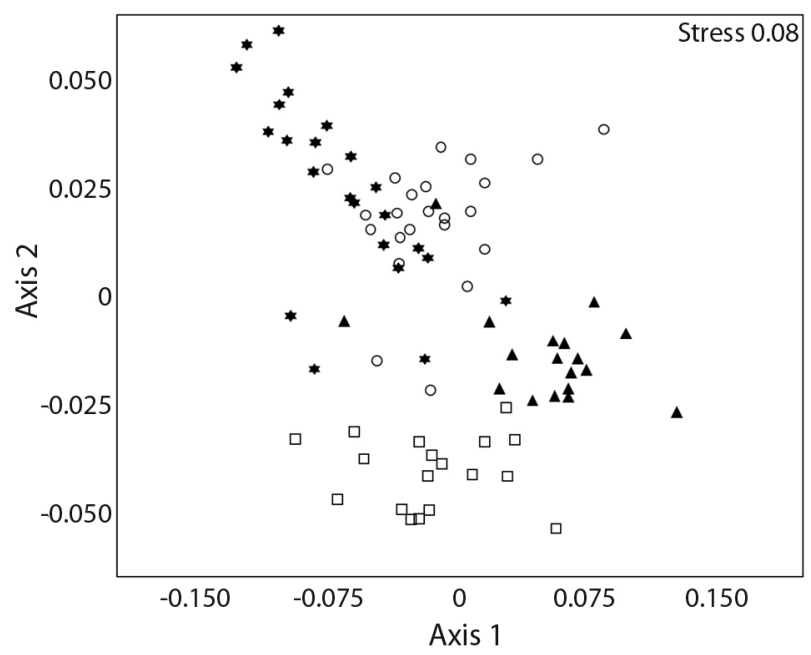

Fig. 2. Non-metric multidimensional scale (NMDS) showing assemblies of ants grouped according to different capture methods (using Bray-Curtis similarity; Stress: 0.08). Star $=$ Sardine, Circle $=$ Banana, Triangle $=$ Non-baited, Square $=$ Manual.

\section{DISCUSSION}

Our results demonstrate that the inventory of ant depends on the sampling methods selected, corroborating other authors' findings (Lee \& Guénard, 2019; Salata et al., 2020). Thus, depending on the objectives of each study (ecological studies or species surveys), different collection methods should be used (Wiezik et al., 2015). We identified that pitfall traps and manual collections provided a different species composition in most of the sampled habitats, which is in agreement with Salata et al. (2020), who recommend using an integrated approach including several complementary methods suitable for the studied habitat.

Both collection methods used in this study have advantages and disadvantages; for example, manual collections involve a direct search for individuals or colonies and are generally considered the most effective method to capture the maximum species richness within a study area (Ellison et al., 2007). However, manual collections are more time-consuming and require a greater number of researchers involved in the fieldwork (Underwood \& Fisher, 2006), and pitfall traps can be installed in the field for several days unattended. However, the use of pitfall traps is limited because they tend to capture larger individuals with high foraging capacity (Martelli et al., 2004), a trend observed in our study. In addition, pitfall traps do not capture the smaller ants that form small colonies (Bestelmeyer et al., 2000; Castilho et al., 2007), so, for these ants, the most suitable method is manual collection (Lindsey \& Skinner, 2001; Véle et al., 2009). We also found that manual collections are more efficient in environments with high litter cover since we observed that, in pasture areas, manual collection did not add any species that had not been collected by pitfall traps (Parr \& Chown, 2001). In fact, we observed that in more anthropogenic habitats (Agriculture \& Pastures), the community comprises mainly generalist ants, with the capacity to use both forest and modified areas, which can be captured through pitfall traps.

In summary, our findings highlight the importance of different sampling methods for collecting ants from the soil, including manual collection, pitfall traps with and without baits, as well as other methods not applied here. This approach can address the different aspects of ant communities that inhabit different ecosystems and, therefore, overcome specific disadvantages of using only a single method to monitor 
changes in the ant community across ecosystem boundaries (Bestelmeyer et al., 2000; Tista $\&$ Fiedler, 2011). Although the use of different sampling methods can be redundant in the ant fauna obtained from comprehensive surveys, it is known that each of them registers a certain fauna, so they are complementary (Wiezik et al., 2015; Antoniazzi et al., 2020). We also stress the importance of studying a greater number of areas with different levels of disturbance. It is important to emphasize that new collections should be standardized for comparison with other studies. Finally, it is essential to consider appropriate methodologies to answer ecological questions, for example, using the same sampling methods when the objective is to compare differences between distinct habitats (Antoniazzi et al., 2020).

Ethical statement: authors declare that they all agree with this publication and made significant contributions; that there is no conflict of interest of any kind; and that we followed all pertinent ethical and legal procedures and requirements. All financial sources are fully and clearly stated in the acknowledgements section. A signed document has been filed in the journal archives.

\section{ACKNOWLEDGMENTS}

WBS thank the Coordenação de Aperfeiçoamento de Pessoal de Nível Superior, Brazil through a doctorate fellowship (Finance Code 001). EP thanks Conselho Nacional de Desenvolvimento Científico e Tecnológico, Brazil for the research grant (Research Productivity $\mathrm{n}^{\circ} 307303 / 2019-5$ ).

\section{RESUMEN}

\section{Muestreo de la diversidad de hormigas en la Amazonía brasileña: una comparación de recolección de hojarasca y trampas de caída}

Introducción: Las hormigas en los bosques tropicales son un grupo hiperdiverso que juega un papel ecológico importante. Varios estudios en los bosques tropicales han utilizado diferentes protocolos de muestreo para capturar las hormigas de suelo, lo que dificulta la comparación de respuestas y patrones de diversidad entre estudios. Por lo tanto, es necesaria una investigación que compare diferentes metodologías de muestreo bien estructuradas y estandarizadas para estimar adecuadamente la riqueza y uniformidad de las especies de hormigas en los bosques tropicales.

Objetivo: En este estudio, examinamos la combinación de capturas con trampas de caída con y sin cebos y recolecciones manuales para muestreo de hormigas en el suelo.

Métodos: En las trampas de otoño, utilizamos dos cebos (sardinas y plátanos) y uno sin cebo. Para las recolecciones manuales (muestreo de hojarasca), se recogió la hojarasca y solo la capa superior de suelo suelto.

Resultados: Encontramos que las trampas que contenían cebos de sardina recolectaron una mayor abundancia de hormigas, mientras que las trampas sin cebo recolectaron una mayor riqueza de especies de hormigas. Por otro lado, las recolecciones de hojarasca capturaron el mayor número de especies exclusivas, presentando una composición de especies diferente a las trampas de caída (con y sin cebo). En general, las trampas con cebo mostraron mayor abundancia en lugares más degradados, mientras que las recolecciones manuales y las trampas sin cebo capturaron más individuos en ambientes preservados.

Conclusiones: Nuestros resultados proporcionan evidencia de que, para un muestreo preciso de ensambles de las hormigas de suelo en los bosques tropicales, el uso de diferentes metodologías es necesario para capturar una mayor diversidad de especies, ya que los métodos difieren en la efectividad de acuerdo con el hábitat.

Palabras clave: comunidad de hormigas; Formicidae; inventario; métodos de muestreo; bosques tropicales.

\section{REFERENCES}

Agosti, D., \& Alonso, L. E. (2001). The all Protocol: a standard protocol for the collection of ground-dwelling ants. Anet Newsletter, 3, 8-11.

Andersen, A. (2019). Responses of ant communities to disturbance: Five principles for understanding the disturbance dynamics of a globally dominant faunal group. Journal of Animal Ecology, 88(3), 350-362.

Andersen, A. N., \& Majer, J. D. (2004). Ants show the way down under: invertebrates as bioindicators in land management. Frontiers in Ecology and the Environment, 2(6), 291-298.

Anderson, M. J. (2001). A new method for non-parametric multivariate analysis of variance. Austral Ecology, 26(1), 32-46.

Antoniazzi, R., Ahuatzin, D., Pelayo-Martínez, J., Ortiz-Lozada, L., Leponce, M., \& Dáttilo, W. (2020). On the effectiveness of hand collection to complement 
baits when studying ant vertical stratification in tropical rainforests. Sociobiology, 67(2), 213-222.

Baccaro, F. B., Feitosa, R. M., Fernández, F., Fernandes, I. O., Izzo, T. J., Souza, J. L. P., \& Solar, R. (2015). Guia Para os Gêneros de Formigas do Brasil. Editora INPA.

Bates, D., Maechler, M., Bolker, B., Walker, S., Christensen, R. H. B., Singmann, H., Dai, B., Scheipl, F., Grothendieck, G., Green, P., \& Fox, J. (2019). Package 'Ime4'. https://cran.r-project.org/web/packages/ lme4/lme4.pdf

Bestelmeyer, B. T., Agosti, D., Alonso, L. E., Brandão, C. R. F., Brown Junior, W. L., Delabie, J. H. C., \& Silvestre, R. (2000). Field techniques for the study of ground-living ants: An overview, description, and evaluation. In D. Agosti, J. D. Majer, L. T. Alonso, \& T. R. Schultz (Eds.), Ants: Standard methods for measuring and monitoring biodiversity (pp. 122-144). Smithsonian Institution Press.

Bolton, B. (1994). Identification Guide to the Ant Genera of the World. Harvard University Press.

Cajaiba, R. L., Périco, E., Dalzochio, M. S., Silva, W. B., Bastos, R., Cabral, J. A., \& Santos, M. G. (2017). Does the composition of Scarabaeidae (Coleoptera) communities reflect the extent of land use changes in the Brazilian Amazon? Ecological Indicators, 74, 285-294.

Cajaiba, R. L., Périco, E., Silva, W. B., Caron, E., Buss, B. C., Dalzochio, M. S., \& Santos, M. (2020). Are primary forests irreplaceable for sustaining Neotropical landscapes' biodiversity and functioning? Contributions for restoration using ecological indicators. Land Degradation \& Development, 31(4), 508-517.

Cajaiba, R. L., \& Silva, W. B. (2014). Mirmecofauna (Hymenoptera, Formicidae) em fragmento florestal urbano no município de Uruará-PA. Enciclopédia Biosfera, 10(18), 2226-2238.

Castilho, A. C. C., Delabie, J. H. C., Marques, M. I., Adis, J., \& Mendes, L. F. (2007). Registros Novos da Formiga Criptobiótica Creightonidris scambognatha Brown (Hymenoptera: Formicidae). Neotropical Entomology, 36(1), 150-152.

Crawley, M. J. (2013). The R book. (2nd Ed.). A John Wiley \& Sons Ltd.

Da Silva, W. B., Périco, E., Dalzochio, M. S., Santos, M., \& Cajaiba, R. L. (2018). Are litterfall and litter decomposition processes indicators of forest regeneration in the neotropics? Insights from a case study in the Brazilian Amazon. Forest Ecology and Management, 429, 189-197.

Del Toro, I., Ribbons, R. R., \& Pelini, S. L. (2012). The little things that run the world revisited: A review of ant-mediated ecosystem services and disservices
(Hymenoptera: Formicidae). Myrmecological News, $17,133-146$.

Delabie, J. H. C., Agosti, D., \& Nacimejnto, I. C. (2000b). Litter ant communities of the Brazilian Atlantic rain forest region. In D. Agosti, J. D. Majer, L. T. Alonso, \& T. R. Schultz (Eds.), Sampling ground-dwelling ants: case studies from the world's rain forests (pp. 1-17). Curtin University School of Environmental Biology.

Delabie, J. H. C., Fisher, B. L., Majer, J. D., \& Wrigth, I. W. (2000a). Sampling effort and choice of methods. In D. Agosti, J. D. Majer, L. E. Alonso, \& T. R. Schultz (Eds.), Ants standard methods for measuring and monitoring biodiversity (pp. 145-154). Smithsonian Institution Press.

Ellison, A. M., Record, S., Arguello, A., \& Gotelli, N. J. (2007). Rapid inventory of the ant assemblage in a temperate hardwood forest: species composition and assessment of sampling methods. Neotropical Entomology, 36(4), 766-775.

Gotelli, N. J., Ellison, A. M., Dunn, R. R., \& Sanders, N. J. (2011). Counting ants (Hymenoptera: Formicidae): Biodiversity sampling and statistical analysis for myrmecologists. Myrmecological News, 15, 13-19.

Hanisch, P. E., Suarez, A. V., Tubaro, P. L., \& Paris, C. I. (2018). Co-occurrence patterns in a subtropical ant community revealed by complementary sampling methodologies. Environmental Entomology, 47(6), 1402-1412.

Ivanov, K., \& Keiper, J. (2009). Effectiveness and biases of winkler litter extraction and pitfall trapping for collecting ground-dwelling ants in northern temperate forests. Environmental Entomology, 38(6), 1724-1736.

Lacasella, F., Gratton, C., Felici, S., Isaia, M., Zapparoli, M., Marta, S., \& Sbordoni, V. (2015). Asymmetrical responses of forest and "beyond edge" arthropod communities across a forest-grassland ecotone. Biodiversity and Conservation, 24(3), 447-465.

Lee, R. H., \& Guénard, B. (2019). Choices of sampling method bias functional components estimation and ability to discriminate assembly mechanisms. Methods in Ecology and Evolution, 10(6), 867-878.

Lindsey, P. A., \& Skinner, J. D. (2001). Ant composition and activity patterns as determined by pitfall trapping and other methods in three habitats in the semiarid Karoo. Journal of Arid Environments, 48(4), $551-568$

Longino, J. T., Coddington, J., \& Colwell, R. K. (2002). The ant fauna of a tropical rain forest: estimating species richness three different ways. Ecology, 83(3), 689-702. 
Lopes, C. T., \& Vasconcelos, H. L. (2008). Evaluation of three methods for sampling ground-dwelling ants in the Brazilian Cerrado. Neotropical Entomology, 37(4), 399-405.

Martelli, M. G., Ward, M. M., \& Fraser, A. M. (2004). Ant diversity sampling on the southern Cumberland Plateau: a comparison of litter sifting and pitfall trapping. Southeastern Naturalist, 3(1), 113-126.

Nakamura, A., Catterall, C. P., House, A. P., Kitching, R., $\&$ Burwell, C. (2007). The use of ants and other soil and litter arthropods as bio-indicators of the impacts of rainforest clearing and subsequent land use. Journal Insect Conservation, 11(2), 177-186.

Orsolon-Souza, G., Esbérard, C. E. L., Mayhé-Nunes, A. J., Vargas, A. B., Veiga-Ferreira, S., \& Folly-Ramos, E. (2011). Comparison between Winkler's extractor and pitfall traps to estimate leaf litter ants richness (Formicidae) at a rainforest site in southest Brazil. Brazilian Journal of Biology, 71(4), 873-880.

Pacheco, R., \& Vasconcelos, H. L. (2012). Subterranean pitfall traps: is it worth including them in your ant sampling protocol? Psyche, 2012, 1-9.

Palácio, E. E., \& Fernández, F. (2003). Claves para las subfamilias y géneros. In F. Fernández (Ed.), Introducción a las hormigas de la región Neotropical (pp. 233-260). Instituto de Investigación de Recursos Biológicos Alexander Von Humboldt.

Parr, C. L., \& Chown, S. L. (2001). Inventory and bioindicator sampling: testing pitfall and Winkler methods with ants in a South African savanna. Journal of the Institute of Conservation, 5(1), 27-36.

R Core Team. (2016). R: A language and environment for statistical computing. R Foundation for Statistical Computing. Vienna, Austria. https://www.R-project. org/

Salata, S., Kalarus, K., Borowiec, T. A., \& Kujawa, K. (2020). How estimated ant diversity is biased by the sampling method? A case study of Crete: a Mediterranean biodiversity hotspot. Biodiversity and Conservation, 29(9), 3031-3050.

Schimidt, F. A., \& Solar, R. C. (2010). Hypogaeic patfall traps: methodological advances and remarks to improve the sampling of a hidden ant fauna. Insectes Sociaux, 57(3), 261-266.

Solar, R. R., Barlow, J., Andersen, A. N., Schoereder, J. H., Berenguer, E., Ferreira, J. N., \& Gardner, T. A.
(2016). Biodiversity consequences of land-use change and forest disturbance in the Amazon: A multiscale assessment using ant communities. Biological Conservation, 197, 98-107.

Sousa-Souto, L. S., Schoereder, J. H., \& Schaefer, C. (2007). Leaf-cutting ants, seasonal burning, and nutrient distribution in Cerrado vegetation. Austral Ecology, 32(7), 758-765.

Souza, J. L. P., Baccaro, F. B., Landeiro, V. L., Franklin, E., \& Magnusson, W. E. (2012). Trade-offs between complementarity and redundancy in the use of different sampling techniques for ground-dwelling ant assemblages. Applied Soil Ecology, 56, 63-73.

Tiede, Y., Schlautmann, J., Donoso, D. A., Wallis, C., Bendix, J., Brand, R., \& Farwig, N. (2017). Ants as indicators of environmental change and ecosystem processes. Indicators Ecological, 83, 527-537.

Tista, M., \& Fiedler, K. (2011). How to evaluate and reduce sampling effort for ants. Journal Insect Conservation, 15(4), 547-559.

Underwood, E. C., \& Fisher, B. L. (2006). The role of ants in conservation monitoring: if, when, and how. Biological Conservation, 132(2), 166-182.

Veiga-Ferreira, S., Orsolon-Souza, G., \& Mayhé-Nunes, A. (2010). Hymenoptera, Formicidae Latreille, 1809: New records for Atlantic Forest in the state of Rio de Janeiro. Check List, 6(3), 442-444.

Véle, A., Holusa, J., \& Frouz, J. (2009). Sampling for ants in different-aged spruce forests: A comparison of methods. European Journal of Soil Biology, 45(4), 301-305.

Wiezik, M., Svitok, M., Wieziková, A., \& Dovčiak, M. (2015). Identifying shifts in leaf-litter ant assemblages (Hymenoptera: Formicidae) across ecosystem boundaries using multiple sampling methods. PLoS ONE, 10, e0134502.

Wong, K. L., \& Guénard, B. (2017). Subterranean ants: summary and perspectives on field sampling methods, with notes on diversity and ecology (Hymenoptera: Formicidae). Myrmecological News, 25, 1-16.

Yusah, K., Fayle, T., Harris, G., \& Foster, W. (2012). Optimizing diversity assessment protocols for high canopy ants in tropical rain forest. Biotropica, 44(1), 73-81. 